\title{
ВОЛОДИМИРУ ВАСИЛЬОВИЧУ ШЕЛЕПОВУ - 75 РОКІВ!
}

B. А. Хаджиматов, кандидат сільськогосподарських наук Державна служба з охорони прав на сорти рослин, С. В. Гаценко, кандидат економічних наук Український інститут експертизи сортів рослин

24 червня 2009 р. виповнилось 75 років старшому науковому співробітнику Українського інституту експертизи сортів рослин, головному редактору науковопрактичного журналу Держсортслужби "Сортовивчення та охорона прав на сорти рослин", головному науковому співробітнику Державної наукової сільського- подарської бібліотеки УААН, доктору сільськогосподарських наук, професору, лауреату державної премії України в галузі науки i техніки Шелепову Володимиру Васильовичу.

Він народився у радгоспі "Щербинівський "Дзержинського району Сталінської (Донецької) області. У 1953 р. закінчив чоловічу середню школу № 1 м. Горлівка Донецької області і поступив учитися на агрономічний фракультет Ставропольського сільськогосподарсько го інституту, який з відзнакою закінчив у 1959 р. за спеціальністю "вчений агроном". Ще студентом проявив здібності до наукової роботи - опублікував першу наукову статтю "Влияние закалки семян на урожай кукурузы" (1956 р.) та неодноразово займав перші місця на мужву- зівських наукових конфреренціях м. Ставрополь.

Після закінчення інституту за направленням працював у радгоспах Красноярського краю (Росія, 1959-1962 рр.) на посадах агронома відділення і головного агронома. Маючи хорошу теоретичну i практичну підготовку, у 1963 р. вступив до аспірантури Всесоюзного селекційногенетичного інституту (тепер Селекційногенетичний інститут - Національний центр насінництва та сортовивчення УААН, м. Одеса). У 1966 р. успішно за 
хистив кандидатську дисертацію в Українському науково-дослідному Інституті рослинництва селекції і генетики (Інтитут рослинництва ім. В. Я. Юр'єва, м. Харків) та отримав благородну для людства профресію селекціонера.

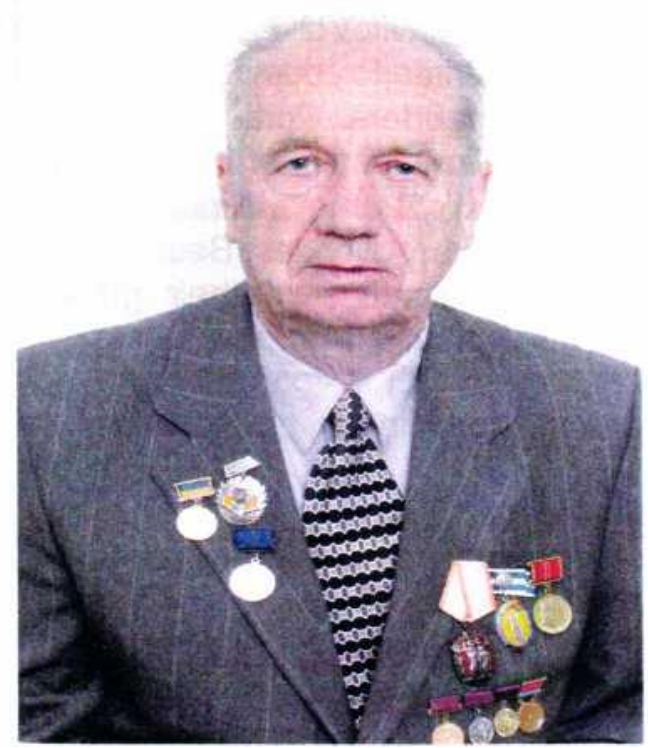

З 1966 по 1985 рр. працював завідувачем відділу селекції Запорізького державної сільськогосподарської дослідної станції. У Запоріжжі В. В. Шелепов наступним після академіка Ф. Г. Кири- ченка, створив сорт пшениці озимої твердої Рубіж, який за врожайністю та зимостійкістю перевищував перші сорти пшениці озимої твердої Мічурінка і Новомічурінка. Сорт Рубіж районований у Запорізькій і Донецькій областях. Згодом були створені і в подальшому районовані сорти пшениці озимої м'якої Запорізька остиста та Запорізька 60. Перший сорт Запорізька остиста був районований в Україні, Росії і Молдові і щорічно висівався на площі більше 500 тис. гектарів.

Двадцять років В. В. Шелепов працював у Миронівському інституті пшениці ім. В. М. Ремесла: у 1985-2003 рр. завідувачем лабораторії селекції інтенсивних сортів пшениці озимої; у 2004- 2005 рр. головним науковим співробітником відділу селекції озимої пшениці.
32005 р. працює старшим науковим співробітником відділу міжнародного співробітництва Українського інституту експертизи сортів рослин Держсортслужби України і головним науковим співробітником відділу наукового реферування інфрормаційної та редакційно-видавничої роботи Державної наукової сільськогосподарської бібліотеки (ДНСГБ) УААН. 1982 р. у Всесоюзному інституті рослинництва ім. М. І. Вавилова (м. Ленінград) і повторно 1992 р. по докладу в інституті рослинництва ім. В. Я. Юр'єва захистив докторську дисертацію на тему "Селекция интенсивных сортов озимой мягкой пшеницы, особенности их семеноводства и сортовой агротехники в условиях Лесостепи и Степи Украины" за спеціальністю 06.01.05-селекція і насінництво.

За цикл наукових праць "Генетичні основи, методи створення нових напівкарликових сортів пшениці м'якої озимої та їх впровадження у виробництво" у 1997 р.. В. В. Шелепову одночасно 3 іншими відомими селекціонерами було присуджено державну премію України в галузі науки і техніки. Цього ж року йому присвоєно звання профресора.

Основні наукові дослідження Шелепова В. В. присвячені теорії і практиці селекції насінництва та агротехніці пшениці м'якої і твердої озимої. Його діяльності притаманні цілеспрямованість і конкретність наукового пошуку. Він перший у колишньому СРСР розробив і застосував у всіх ланках селекційного процесу методику створення штучних інфекційних (програма "Імунітет") і провокаційних фонів з метою оцінки і добору комплексно стійких проти хвороб, високозимостійких сортів пшениці озимої, розробив і застосував у селекції принципи моделювання підбору батьківських фрорм та бракування гібридів $F_{1}, \mathrm{~F}_{2}$ з використанням електронно-обчислювальних машин (ЕОМ), прийоми прискореного розмноження й впровадження нових сортів у виробництво.

В. В. Шелепов - автор 35-ти районованих в Україні, Росії, Білорусі та Молдові сортів пшениці озимої; 25-ти джерел та донорів пшениці озимої м'якої та твердої 3 окремих ознак занесених до 
світової колекції рослин у Всесоюзному інституті рослинництва ім. М. І. Вавилова. Найбільш відомі його сорти пшениці: Рубіж (озима пшениця), Запорізька остиста, Миронівська 27, Миронівська 30, Миронівська ранньостигла, Ремеслівна, Крижинка, Деметра тощо. Опублікував більше 250 наукових праць, серед них чотири монографрії: "Озимая твердая пшеница" (1978р.), "Морфология, биология и хозяйственное значение пшеницы" (2004р.), "Селекція, насінництво та сортовивчення пшениці" (2007р.), "Пшеница: история, морфология, біологія, селекция" (2009р.). Він е членом редколегій журналів: "Науковотехнічний бюлетень Миро- нівського інституту пшениці ім. В. М. Ремесла", "Історія освіти, науки і техніки в Україні" ДНСГБ УААН, головним редактором журналу "Сортовивчення та охорона прав на сорти рослин" Держсорт- служби України, членом спеціалізованих рад по захисту кандидатських й докторських дисертацій при ДНСГБ УААН та Південному фріліалі "Кримський агротехнологічний університет" Національного університету біоресурсів і природокористування.

В. В. Шелепов активно співпрацював 3 селекціонерами і науковцями інших установ. Спільно з Інститутом захисту рослин УААН виконував державну програму "Імунітет", в результаті якої створено сорти пшениці Деметра (Миронівська 35) і Економка, низка сортів:
Крижинка, Переяславка, Смуглянка, Володарка та інші, 3 Інститутом фрізіології рослин і генетики НАН України (програма "Мутагенез"); із Самарським НДІСГ (Росія) сорт Сніжинка (програма "зимостійкість"). Особистий досвід та знання посприяли запрошенню відвідування й ознайомлення з селекційними досягненнями фірми "Вільморенів" (Франція); інституту Угорської академії сільськогосподарських наук; сільськогосподарської академії Китаю та країн СНД.

За профресійні заслуги Володимира Васильовича нагороджено орденом "Знак пошани", медаллю "За доблесну працю", "Знаком Пошани" Мінагрополі- тики України, "Відмінник аграрної науки і освіти", неодноразово нагороджувався золотими й срібними медалями ВДНГ СРСР, України, е лауреатом ВДНГ СРСР, має почесне звання "Винахідник СРСР".

Багато сил і енергії профресор Шелепов В. В. віддає роботі $з$ молодими селекціонерами, виховуючи гідну зміну, яка примножує славу селекціонерівпшеничників. 3 його допомогою захищені сім дисертацій на здобуття наукового ступеня кандидата сільськогосподарських наук.

В. В. Шелепов не втрачає творчої наснаги, веде велику наукову, консультативну i педагогічну роботу. Бажаємо Володимиру Васильовичу міцного здоров'я, творчого довголіття та успіхів у справі його життя! 